\title{
POLITECH (The Prototype Development of Plastic Waste Converter Machines Into Liquid Fuels with Continuous System Capacity 3,5 L)
}

\author{
Febby Atridya $\mathrm{a}^{*}$, Ayu Suandari Larasati a and Ridwan a \\ ${ }^{a}$ Department of Mechanical Engineering, State Polytechnic of Jakarta, A.W. Siwabessy Street, Kampus Baru UI, Depok, Indonesia
}

\begin{abstract}
In 2008, the estimate amount of landfill waste in Indonesia reached 38.5 million tons every year with the largest compositions are organic waste (58\%), plastic waste (14\%), paper waste (9\%) and wood waste (4\%). Among waste compositions, only plastic waste takes the longest time of decomposition, about 100-500 years. This is because the characteristic of plastic is unravel which can lead to pollution of land, water and air. To overcome these problems, many people try to find solutions for plastic wastes such as burn, bury and recycle plastic wastes. But, all these ways still have negative impacts for the environment and the safety of the workers who do the combustion process. Therefore, it is a conversion machine that can convert plastic wastes into fuel with pyrolisis system, it burn plastic wastes in vacuum condition. This machine has several advantages, which have a high calorific value of the fuel (equivalent calorific value premium), and this machine can reduce a lot of plastic wastes, reached 92 kilos/ 8 hour every day for 2 kilos reactor capacity, and it's also safety for environment because the plastic wastes are burnt in the reactor with $900^{\circ} \mathrm{C}$ heat. So, the process and the oil are not produces dioxine gas. The innovations of this conversion of plastic waste machine are, it has a continuous pipe that can put $0.3 \mathrm{~kg}$ of plastic waste within 1.5 minutes while the machine is operating.
\end{abstract}

Keywords: plastic waste, conversion machine, pyrolysis, liquid fuel

\section{Introduction}

Waste is the last result of human activities and natural processes. The wastes have no economic value anymore. It can even cause negative impacts. In 2008, the estimated amount of landfill waste in Indonesia reached 38.5 million tons every year with the largest compositions are organic waste (58\%), plastic wastes $(14 \%)$, paper wastes $(9 \%)$ and wood wastes $(4 \%)$. (Indonesia Ministry of Environment, 2008). Among waste compositions, only plastic waste takes the longest time of decomposition, it's about 100-500 years. The characteristic of plastic is unravel which can lead to pollution of land, water and air. The processing by burning the plastic wastes will produce toxic substances from plastic waste that release into the atmosphere. It can cause adverse health effects. Processing by burying the plastic wastes will not solve the problem, because the plastic is not derived from biological compounds, it will remains in the soil. While in the plastic recycling process waste only some of particular plastics type that can be processed, plastic waste in the form of plastic bags are not used in the recycling process.

The solution we bring is made a conversion machine of plastic waste into fuel. This is feasible because basically plastic derived from oil. Research on machine conversion of plastic waste into fuel has been tested on a sample of $1 \mathrm{~kg}$ of plastic waste that produces $300 \mathrm{ml}$ plastic fuel, tested on a machine with heating temperature $530^{\circ} \mathrm{C}$, the input power of 3000 watts and engine testing time for 2 hours, can produce fuel up to $300 \mathrm{ml}$ with a calorific value of $44040.95 \mathrm{~J} / \mathrm{g}$ or equivalent premium $43061.24 \mathrm{~J} / \mathrm{g}$. (Sapriyanto, 2011).

Based on these tests, we have innovative ideas to improve the efficiency of the conversion machine, by increasing the capacity of the machine to become $3.5 \mathrm{~L}$,

Corresponding author: Tel: +62-8568016942

E-mail: febbyatridya@gmail.com 
using a continuous system for the machine to process waste plastics constantly and high temperature operating.

\section{Material and Method}

The writing of this papers use the literature method. The study of literature is a critical analysis of the literature collection that contains materials consisting of source books and journals, archival sources, official documents, and electronic publications. Objective study of the literature in this paper is the basis for the establishment plan of the early writing and as the secondary data source. The literature method is conducted by data collection, data processing, data analysis and compilation framework.

\subsection{Collecting Data}

Collecting data is performed by assessment of reading materials in the books, theses, journals, electronic journals, and other literature relating to plastics, fuel, plastic waste, and make a survey for the final waste treatment facility in Depok. It is intended to make the problems described is easier to understand.

\subsection{Data processing}

This writing will begin with collecting data which is categorized by the authors to describe how the use of the machine conversion of plastic waste into fuel effect on the reduction of the amount of plastic waste in the TPAS, particularly in the city of Depok. Then, it will be elaborate on how the notion of plastic, plastic classification, methods of plastic waste management, fuel classification, and the use of the conversion machine of plastic waste into oil. This activity carried out in several stages, there are

\subsubsection{Group Discussion}

In the discussion group will discuss what should be done next. Start with planning tool manufacture, the manufacture of tools, testing tools, analysis of test results, the introduction of plastic waste, operation of equipment, preparation of reports and a last group. Maturation plan for determine the success of this activity.

\subsubsection{Planning Preparation tool}

Manufacturing planning tool is a preparatory step before making this machine. The activity is to understanding the work principle of this machine and the design sketching of machine. In this activity, each member has their respective duties for the next step. 2.2.3 Machine Making
At this stage, the manufacturing of conversion machine of plastic wastes is processing. This process requires quite a long time, because the production of machine should be careful to produce a perfect result for setting up plastic waste processing equipment required teamwork coherent and mutually supportive.

\subsubsection{Machine Testing}

In this activity, the machine is tested. Is the result met the target or still need component to be added. The machine testing can be used as a benchmark and input for this activity.

\subsubsection{Analysis of Testing Results}

Analysis of the machine testing results is an important stage in this activity. We can know about the weakness of this machine and then recover it. The expectation is to analyze the data that is useful for the next step.

\subsubsection{Introduction of Plastic Waste Processing}

This activity is intended to introduce to the public around waste bank about the conversion plastic wastes into fuel oil. Socialization to the public about the conversion plastic wastes into fuel is very important. This is because without the role of local communities, the program is not running as same as the targets.

\subsection{Data Analysis}

After performing the steps above then the machine is tested against the plastic waste materials that have been classified by type, then the results will be compared with the theoretical calculation of the efficiency, calorific value of the fuel, the volume of fuel produced, and time of heating plastic waste after conclusion was made. In order for the final conclusions obtained are relevant to issues in the actual and already have gone through a comprehensive compilation based on accurate data that can be analyzed in a coherent and useful for subsequent research.

The design of conversion machine with continuous system and reservoir steam-wet oil is based from this description. Description of previous technologies and technical problems associated with it.

Identify weaknesses of existing technologies /earlier in addressing :

1. Processing of plastic waste into oil by pyrolysis process by Aprian Ramadan, UPN-veteran. 2011

- The value of activation energy $12145.4 \mathrm{cal} / \mathrm{mol}$

- The processing time of $60 \mathrm{~min}$. with a temperature of $420^{\circ} \mathrm{C}$

2. Plastic Waste Converter Machines Become Fuel Oil by Agus Sapriyanto, PNJ PKMT 2011 
- The design does not meet the security aspects

- There is heat coming out

- The process of distillation

- The calorific value of $9758 \mathrm{kcal} / \mathrm{kg}$

- There is a burning gas losses so that not all gas distilled

- Fuel produced turbid

- Have a long intervals of condensation plastic into plastic fuel

\section{Result and Discussion}

If this machine applied in the industries of plastic waste and plastic waste pickers associations:

Industry / Unit Waste Plastics:

a. Industry insiders can gain from the sale of fuel

b. Actors can employ the industry-about as many as 10 plastic garbage collectors person / unit device
So we can conclude the above disadvantages of the three innovations are:

1. Time tool operation

2. The volume of fuel produced

3. The efficiency of the tool.

From this description we made a new design that will increase the efficiency of this machine. The design is made with continuous system and reservoir wet steam oil which can burn plastic waste more and increase the volume of plastic oil that conversion machine produce.

Plastic garbage collector can earn extra income per day

The benefits of innovation for the environment

a. Reduce plastic waste

b. Reduce the impact of plastic waste pollution caused by the burning of plastic waste

c. Reduce the impact of plastic waste pollution caused by waste burial

d. Reducing the use of fossil energy, namely solar.

Association of plastic garbage collector:

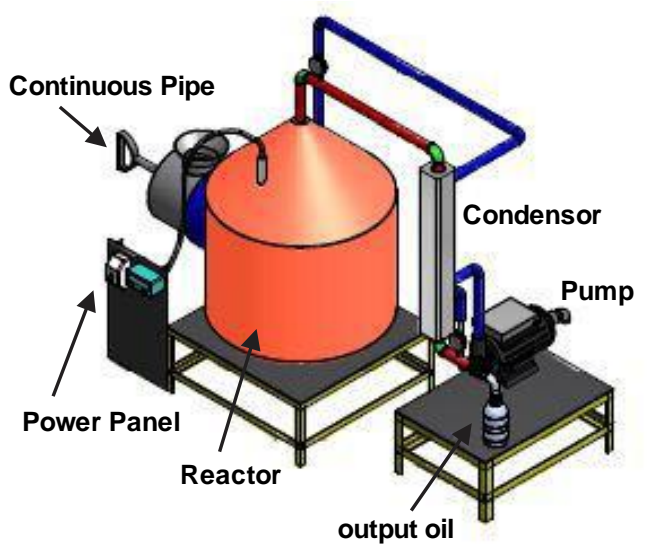

Fig. 1 The design of conversion machine 
Table.1

Calorific value test result from previous research

\begin{tabular}{lccccc}
\hline \multicolumn{1}{c}{ NAME } & MASS & $\begin{array}{c}\text { CV } \\
\text { (CAL/g) }\end{array}$ & $\Delta$ T & $\begin{array}{c}\text { FUSE } \\
\text { LENGTH } \\
\text { (cm) }\end{array}$ & $\begin{array}{c}\text { MET } \\
\text { HOD }\end{array}$ \\
\hline Plastic & $1 \mathrm{gr}$ & 10519 & 4,114 & 10 & 1000 \\
waste fuel & & & & & \\
Solar & $1 \mathrm{gr}$ & 10896 & 4,274 & 10 & 1000 \\
Premium & $1 \mathrm{gr}$ & 10285 & 3,993 & 10 & 1000 \\
Kerosin & $1 \mathrm{gr}$ & 11021 & 4,314 & 10 & 1000 \\
Pertamax & $1 \mathrm{gr}$ & 11729 & 4,066 & 10 & 1000
\end{tabular}

(tests were conducted in the lab. Energy Conversion Engineering PNJ)

Testing the calorific value that we do is test 1 gr of plastic waste oil sample using Bomb Calorimeter. Once tested, the values obtained for $10,519 \mathrm{Cal} / \mathrm{g}$ or $44,040.95 \mathrm{~J} / \mathrm{g}$.

As a comparison variables, testing is also conducted on four types of fuel that we buy in the market, there are Solar, premium, gasoline and pertamax.

\section{Conclusion}

The result if used this conversion machine of plastic into oil fuel with continuous system oil with $3,5 \mathrm{~L}$ capacity is can reduce the plastic waste as $92 \mathrm{~kg} /$ day and will increase the efficiency til 0.43 . Plastic waste fuel, which is the outcome from plastic waste conversion machine with continuous system, can be used as fuel for vehicles, it is because the plastic oil calorific value $10,519 \mathrm{cal} / \mathrm{g}$ equivalent calorific value premium. This research is expected to address the scarcity of fossil fuels, and increasing public awareness of using alternative fuel, especially plastic waste fuel.

\section{References}

Lee, K.H., Shin, D.H. \& Seo, Y.H. (2003) Liquid-Phase Catalytic Degradation of Mixture of Waste High Density Polyethylene and Polystyrene Over Spent FCC Catalyst, Effect of Mixing Proportions of Reactant. Polym Degrad Stab, 84,123-127.

Mujiarto, Iman. (2005) Sifat Dan Karakteristik Material Plastik Dan Bahan Aditif, Semarang

Sapriyanto, Agus. (2011) Mesin Pengubah Sampah Plastik Menjadi Bahan Bakar Minyak, PKMT PNJ,Depok.
[Dep. ESDM] DepartmenEnergi dan Sumber Daya Mineral. 2008. Kemajuan Pemanfaatan Bahan Bakar Nabati (BBN). Dep. ESDM, Jakarta.

Kementrian Negara Lingkungan Hidup. (2008) Kemen LH RI, Jakarta. Kepala Unit Pelaksana Teknis Dinas Kebersihan Pertamanan Kota Depok, (2012)

Mujiarto, Iman. (2005) Sifat Dan Karakteristik Material Plastik Dan Bahan Aditif, Semarang.

Ermawati, Rahyani. (2011) Konversi Limbah Sampah Plastik Sebagai Sumber Energy Alternative.Balai Besar Kimia dan Kemasan, Kementrian Perindustrian. Jurnal Riset Industri Volume V, No.3, 257-258.

Napitupulu, Farel H. (2006) Pengaruh Nilai Kalor (Heating Value) Suatu Bahan Bakar Terhadap Perencanaan Volume Ruang Bakar Ketel Uap Berdasarkan Metode Penentuan Nilai Kalor Bahan Bakar Yang Diperlukan.Jurnal Sistem Teknik Industri Volume 7, No.1, Sumatra Utara.

Zuhra, Cut Fatimah, Ssi.Msi. (2003) penyulingan, pemrosesan dan penggunaan minyak bumi, Universitas Sumatra Utara.

Kenkel, J. (2002) Analytical Chemistry for Technicians, 3th.Edition, CRC Press, U.S.A.

Sinaga, E. (2006) Bahaya Zat racun dioxine dari pembakaran sampah. 